\title{
Some hematological and biochemical parameters and steroid hormone levels in the one-humped camel during different physiological conditions
}

\author{
M. A. Ayoub ${ }^{1}$, A. A. El-Khouly ${ }^{2}$ and T. M. Mohamed ${ }^{2}$ \\ ${ }^{1}$ Department of Aridland Agriculture., College of Food Systems, UAE University, Al-Ain, \\ P.O. Box 17555, ${ }^{2}$ Vet. Lab. Department of Agriculture and Animal Resources, Veterinary \\ Laboratory, Al-Ain, United Arab Emirates.
}

\begin{abstract}
Four non-pregnant, 4 late pregnant and 3 cycling camels were used for blood collection to determine estradiol-17 $\beta$ and progesterone concentrations. Blood hematological and serum biochemical parameters were determined in non-pregnant and late pregnant camels. Hematological parameter levels varied between pregnant and non-pregnant camels. Equal values for packed cell volume (PCV), hemoglobin (Hb) and total white blood cell (WBC) counts were found in both groups. However, neutrophils and eosinophils showed higher $(\mathrm{P}<0.05)$ levels in the pregnant than those in non-pregnant camels. An opposite trend was found for lymphocytes $(\mathrm{P}<0.05)$ and monocytes. On the other hand, serum biochemical parameters showed elevated $(\mathrm{P}<0.05)$ levels in total protein, albumin, globulin $(\mathrm{P}>0.05)$, blood urea nitrogen, and creatinine in pregnant than in non-pregnant animals. However, total creatine kinase, alkaline phosphatase, alanine aminotransferase, aspartate aminotransferase, gamma-glutamyl transferase, lactic dehydrogenase and glucose showed lower $(\mathrm{P}<0.05)$ levels in pregnant than in non-pregnant camels. Levels of estradiol-17 $\beta$ ranged from 1.29 to $13.42,240.95$ to 628.29 and 5.72 to $29.69 \mathrm{pg} / \mathrm{ml}$ in the non-pregnant, pregnant and in camels during estrous cycle, respectively. Progesterone levels ranged from 0.29 to $2.87,1.40$ to 6.45 and 0.50 to $1.80 \mathrm{ng} / \mathrm{ml}$ in non-pregnant, pregnant and in camels during estrous cycle, respectively. Levels of estradiol-17 $\beta$ did not exceed $13.42 \mathrm{pg} / \mathrm{ml}$ in the non-pregnant not-cyclic camels, while it reached $29.69 \mathrm{pg} / \mathrm{ml}$ at standing estrus. However, in pregnant camels, estradiol-17 $\beta$ increased steadily up to 628.29 $\mathrm{pg} / \mathrm{ml}$ near parturition. Then it decreased to $20.36 \mathrm{pg} / \mathrm{ml}$ after parturition, suggesting a possible fetoplacental involvement in estradiol-17 $\beta$ secretion. Progesterone concentration increased during pregnancy up to $6.45 \mathrm{ng} / \mathrm{ml}$. Then it decreased to reach 1.19 to $2.47 \mathrm{ng} / \mathrm{ml}$ after parturition.
\end{abstract}

Key Words: blood, enzymes, estradiol, progesterone, camel.

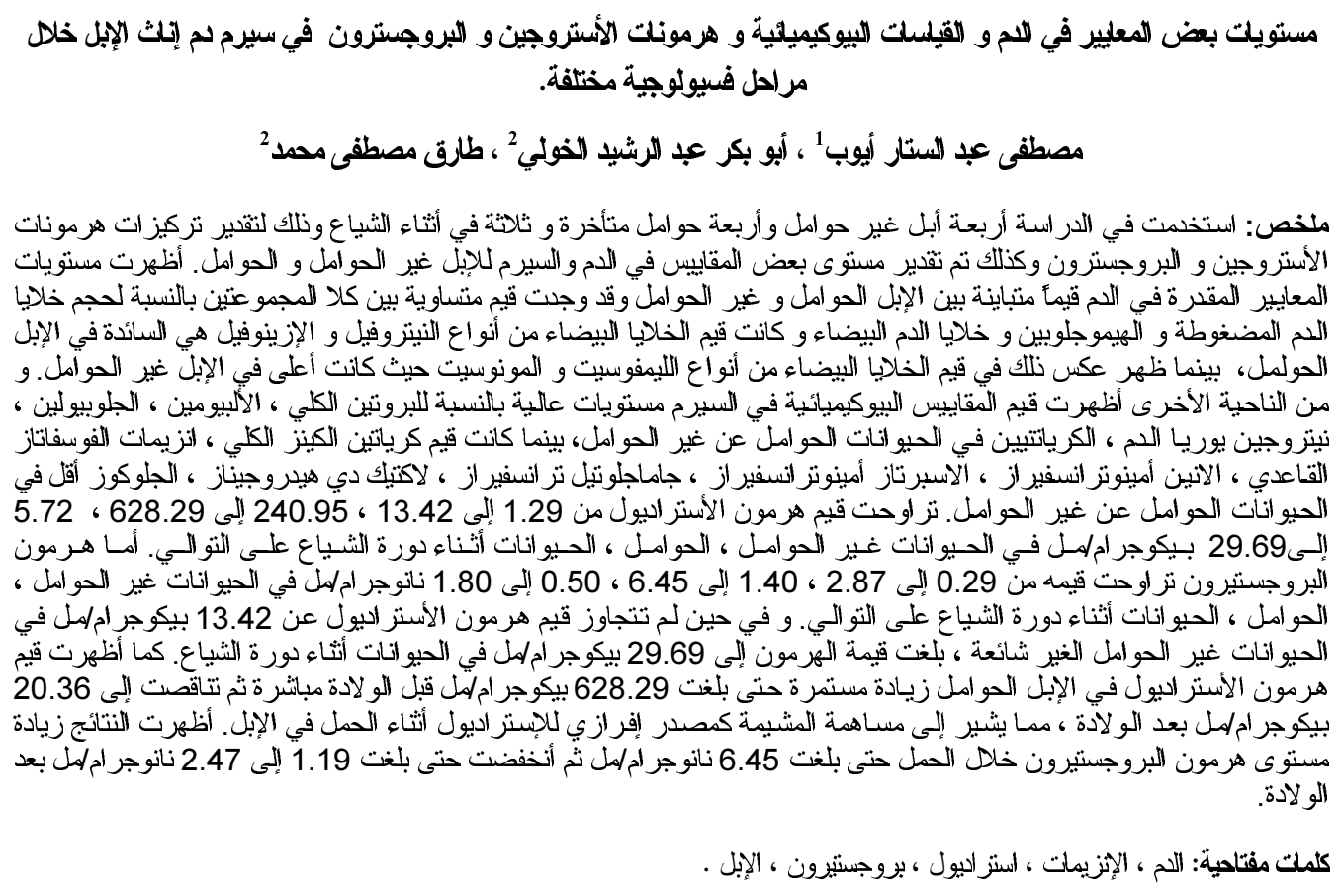

\section{Introduction}

Progesterone and estradiol hormonal profiles during different reproductive conditions have been characterized in many domestic animals. However, only few reports have studied the hormonal profiles of progesterone and estradiol in camels. Skidmore et al. (1996a) studied the ovarian follicular wave patterns 
ultrasonographically in camels and found that the follicular cycle was divided into a growth phase (10.5+0.5 days), a mature phase $(7.6 \pm 0.8$ days $)$ and a regression phase $(11.9+0.8$ days $)$. They found that serum estradiol-17 $\beta$ concentration reached a peak value of $39 \mathrm{pg} / \mathrm{ml}$ at estrus when the dominant follicle reached a mean diameter of $1.7 \mathrm{~cm}$ and, after ovulation, mean serum concentration of progesterone reached a peak value of $2.6 \mathrm{ng} / \mathrm{ml}$ on day 8 .

Progesterone is high during pregnancy and falls just before parturition, while estradiol increases steeply before parturition in cattle, sheep, goats, and pigs (Bassett et al, 1969, Thorburn et al, 1972; Robertson and King, 1974, and Peterson et al, 1975). Elias et al (1984) measured estradiol-17ß concentrations at monthly intervals in pregnant camels and found that the concentrations remained constant at 50$100 \mathrm{pg} / \mathrm{ml}$ during the first 10 months of gestation before rising to a peak during the twelfth month. The same observation was reported by Skidmore et al. (1996b), where estradiol-17 $\beta$ concentrations increased around day 50 to about $100 \mathrm{pg} / \mathrm{ml}$, then remained relatively constant until day 300 . The follicular wave duration in the dromedary camels was reported to range from 17.2 to 23.4 days in India (Joshi et al., 1978), mean duration of 24.2 days in Egypt (Wilson, 1984) and 28 days in Sudan (Musa and Abusineina, 1978).

The objectives of the present study were to determine reference ranges for some hematological and serum biochemical values and hormonal levels of estradiol-17 $\beta$ and progesterone in female camels at various ages and different physiological conditions under United Arab Emirates (UAE) climate.

\section{Materials and Methods}

Eleven female camels were used in this study. They were housed in open yards at the College of Food Systems Experimental Farm, UAE University, during the breeding season from October to April 98/99. Each camel was offered $2-2.5 \mathrm{~kg}$ concentrate mixture $(12 \% \mathrm{CP}), 250$ grams of dates, and hay ad libitum. All animals were regularly checked for any clinical diseases. Blood samples for the determination of hematological and biochemical parameters were collected (jugular vein) from four animals each of late pregnant (6-10 years of age and over 10 months of pregnancy) and non-pregnant (3-4 years of age) camels every $72 \mathrm{hrs}$ for 10 consecutive times. The determined parameters in the whole blood were packed cell volume (PCV), hemoglobin ( $\mathrm{Hb}$ ), white blood cell (WBC), and white blood cell differential count percentages $(\mathrm{N}$, neutrophils; L, lymphocytes; M, monocytes; and E, eosinophils). The following parameters were also determined in sera: glucose, total protein (TP), albumin (ALB), globulin (GLO), blood urea nitrogen (BUN), creatinine (Crea), creatinekinase $(\mathrm{CK})$, alkaline phosphatase (Alph), alanine aminotransferase (ALT), aspartate aminotransferase (AST), gammaglutamyl transferase (GGT), lactic dehydrogenase (LDH). Blood hematology and biochemical analyses were determined by using Dimension Clinical Chemistry System (Coulter Counter, T890) at the Veterinary Laboratory, Department of Agriculture and Livestock, Al-Ain, UAE. Blood samples for the determination of estradiol-17 $\beta$ and progesterone concentrations were collected from four non-pregnant not cycling camels (3-4 years of age) once every other week for 10 weeks, and three camels (6-8 years of age) at standing estrus ( 7 samples) for 18 days during the estrous cycle. Estrus was detected every day by using a sexually mature male camel. In addition, blood samples were collected (every $72 \mathrm{hrs}$ ) from four late pregnant camels (6-10 years of age) for 10 consecutive times at the end of 
pregnancy and continued for nine days after parturition. Sera were collected and kept at $-20 \quad{ }^{0} \mathrm{C}$ until hormonal determinations. Estradiol-17 $\beta$ and progesterone hormones were determined in serum samples using solid phase fluoroimmunoassay $\quad$ DELFIA $^{\circledR}$ kits, WALLAC oy, Turku, Finland).

The lower limit of detection for oestradiol-17 $\beta \quad(95 \% \quad \mathrm{~B} / \mathrm{Bo})$ was 0.065 $\mathrm{pg} / \mathrm{ml}$ serum, and the intra- and inter-assay coefficients of variation (CV) were $6.20 \%$ and $10.20 \%$, respectively. The lower limit of detection for progesterone $(95 \% \mathrm{~B} / \mathrm{Bo})$ was $0.039 \mathrm{ng} / \mathrm{ml}$ serum, and the intra- and inter-assay were $7.17 \%$ and $6.87 \%$, respectively.

\section{Statistical Analysis}

Complete randomized design (CRD) according to Snedecor and Cochran (1980) was applied to analyze data by using Costat Statistical Program. The following model was used:

$Y=u+A_{i}+T_{j}+A^{*} T_{i j}+e_{i j k}$

Where: $\mathrm{u}=$ overall mean, $\mathrm{A}_{\mathrm{i}}=$ animal effect, $T_{j}=$ time effect, $A^{*} T_{i j}=$ animal $X$ time interaction effect, $\mathrm{e}_{\mathrm{ijk}}=$ random error. Duncan's (1955) multiple range test and student $\mathrm{T}$ test were used to compare means at $\mathrm{P}<0.05$.

\section{Results}

Table 1 shows the levels of some hematological parameters determined in pregnant and non-pregnant camels. The levels of the determined hematological parameters fell within normal ranges, and no significant differences $(\mathrm{P}>0.05)$ were found between pregnant and non-pregnant camels in the determined parameters except for neutrophils, lymphocytes and esinophyles percentages. Pregnant camels showed higher $(\mathrm{P}<0.05)$ values of neutrophils and esinophyles and lower values for lymphocytes than those found in the non-pregnant animals. Table 2 shows the levels of some biochemical parameters in pregnant and non-pregnant camels. Pregnant camels showed higher $(\mathrm{P}<0.05)$ values for serum total protein, albumin, blood urea nitrogen and creatinine, and lower $(\mathrm{P}<0.05)$ values for serum $\mathrm{CK}$, Alph, AST, GGT, LDH and glucose, ALT $(\mathrm{P}>0.05)$ in non-pregnant camels.

Table 1. Levels of some hematological parameters in pregnant and nonpregnant camels (mean \pm S.E).

\begin{tabular}{lcc}
\hline \multicolumn{1}{c}{ Parameter } & Pregnant & Non-pregnant \\
\hline PCV (\%) & $26.88+0.39$ & $27.00 \pm 0.37$ \\
Hemoglobin $(\mathrm{gm} / 100 \mathrm{ml})$ & $12.43+0.19$ & $12.43 \pm 0.18$ \\
WBC (X103) & $10.54+0.25$ & $11.28 \pm 0.24$ \\
Neutrophils (\%) & $61.15+1.79 \mathrm{a}$ & $53.63 \pm 2.38 \mathrm{~b}$ \\
Lymphocytes (\%) & $30.50+1.95_{\mathrm{a}}$ & $40.43 \pm 2.48 \mathrm{~b}$ \\
Monocytes $(\%)$ & $2.78+0.21$ & $2.88 \pm 0.74$ \\
Eosinophils $(\%)$ & $5.43+0.45_{\mathrm{a}}$ & $3.60 \pm 0.35 \mathrm{~b}$ \\
\hline $\mathrm{a}, \mathrm{b}$ Denote differences between means in the same row $(\mathrm{P}<0.05)$
\end{tabular}


Table 2. Levels of some biochemical parameters in pregnant and non-pregnant camels (mean+S.E).

\begin{tabular}{|c|c|c|}
\hline Parameter & Pregnant & Non-pregnant \\
\hline Glucose $(\mathrm{mg} / 100 \mathrm{ml})$ & $96.58+1.53$ & $100.55+1.03$ \\
\hline Total Protein $(\mathrm{gm} / 100 \mathrm{ml})$ & $6.43 \pm 0.04$ a & $5.95+0.08_{b}$ \\
\hline Albumin (gm/100ml) & $2.70 \pm 0.05 \mathrm{a}$ & $2.49+0.02 \mathrm{~b}$ \\
\hline Globulin $(\mathrm{gm} / 100 \mathrm{ml})$ & $3.74 \pm 0.04$ & $3.51+0.06$ \\
\hline BUN (mg/100ml) & $15.48 \pm 1.45 \mathrm{a}$ & $7.85+1.45 \mathrm{~b}$ \\
\hline Creatinine $(\mathrm{mg} / 100 \mathrm{ml})$ & $1.42 \pm 0.04 \mathrm{a}$ & $1.20+0.06 \mathrm{~b}$ \\
\hline $\mathrm{CK}(\mathrm{U} / \mathrm{L})$ & $23.25 \pm 2.21 \mathrm{a}$ & $55.96+4.54_{b}$ \\
\hline Alkaline Phosphatase (U/L) & $44.27 \pm 1.93 \mathrm{a}$ & $73.75+2.42 \mathrm{~b}$ \\
\hline $\operatorname{ALT}(\mathrm{U} / \mathrm{L})$ & $13.13+0.36$ & $18.56+0.24$ \\
\hline AST (U/L) & $53.88+0.88$ a & $77.15+1.41_{b}$ \\
\hline GGT (U/L) & $8.83 \pm 1.40 \mathrm{a}$ & $11.08+2.28 \mathrm{~b}$ \\
\hline $\mathrm{LDH}(\mathrm{U} / \mathrm{L})$ & $297.00 \pm 9.24 \mathrm{a}$ & $428.58+13.0_{b}$ \\
\hline
\end{tabular}

Table 3 and Figure 1 show levels of serum estradiol-17 $\beta$ and progesterone during 10 weeks in non-pregnant camels at 3-4 years of age. Estradiol-17 $\beta$ concentration ranged from 1.29 to $13.42 \mathrm{pg} / \mathrm{ml}$, and progesterone concentration ranged from 0.29 to 2.87 $\mathrm{ng} / \mathrm{ml}$ during 8 and 10 weeks of the study, respectively. Progesterone concentrations remained below $1 \mathrm{ng} / \mathrm{ml}$ during the first 4 weeks, where estradiol-17 $\beta$ levels were low, then progesterone level increased $(\mathrm{P}<0.05)$ to $2.87 \mathrm{ng} / \mathrm{ml}$ at the $6^{\text {th }}$ week and declined $(\mathrm{P}<0.05)$ to 1.52 and $1.57 \mathrm{ng} / \mathrm{ml}$ during the $8^{\text {th }}$ and $10^{\text {th }}$ weeks, respectively.

Table 3. Levels of serum estradiol and progesterone hormones in non-pregnant camels (mean \pm S.D).

\begin{tabular}{|c|c|c|}
\hline Weeks & Estradiol $(\mathrm{pg} / \mathrm{ml})$ & Progesterone (ng/ml) \\
\hline 0 & $2.66+1.98 \mathrm{~b}$ & $0.39 \pm 0.44_{\mathrm{c}}$ \\
\hline 2 & $1.29 \pm 1.41_{\mathrm{b}}$ & $0.29 \pm 0.26_{\mathrm{c}}$ \\
\hline 4 & $3.20 \pm 4.15 \mathrm{~b}$ & $0.77 \pm 1.18 \mathrm{bc}$ \\
\hline 6 & $10.72+0.92$ a & $2.87 \pm 0.67 \mathrm{a}$ \\
\hline 8 & $13.42+3.20 \mathrm{a}$ & $1.52 \pm 0.87 \mathrm{~b}$ \\
\hline 10 & ND & $1.57 \pm 0.19 \mathrm{~b}$ \\
\hline
\end{tabular}




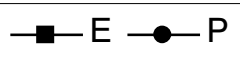

917

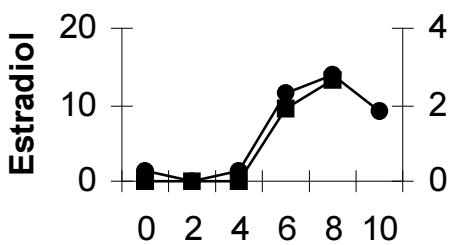

50

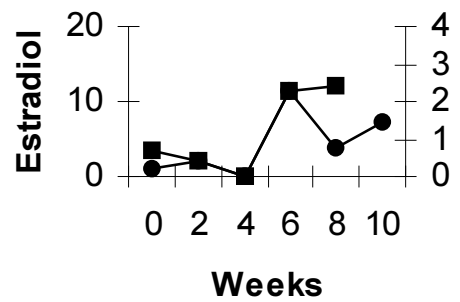

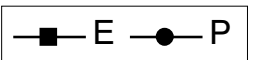

910

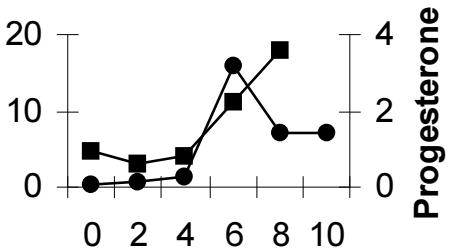

100

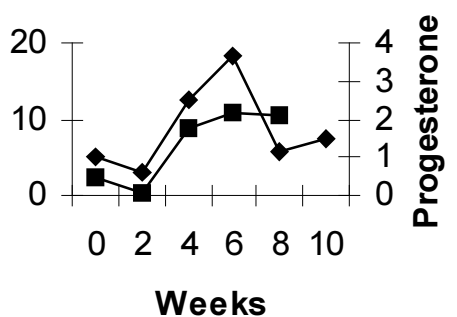

Figure 1. Serum levels of estradiol $(\mathrm{pg} / \mathrm{ml})$ and progesterone $(\mathrm{ng} / \mathrm{ml})$ during 10 weeks in 4 immature camels.

Estradiol-17 $\beta$ reached the highest $(\mathrm{P}<0.05)$ concentration $(29.7 \mathrm{pg} / \mathrm{ml})$ at standing estrus, decreased gradually to $5.7 \mathrm{pg} / \mathrm{ml}$ at the $7^{\text {th }}$ day, then increased insignificantly (10.6 to 12.7 $\mathrm{pg} / \mathrm{ml}$ ) during the rest of the cycle at the day 18 (Table 4 and Figure 2). On the other hand, progesterone levels remained below $1 \mathrm{ng} / \mathrm{ml}$ ( 0.5 to $0.7 \mathrm{ng} / \mathrm{ml})$ during the first 3 days of the estrous cycle, and then increased insignificantly to above $1 \mathrm{ng} / \mathrm{ml}$ ( 1 to 1.8 $\mathrm{ng} / \mathrm{ml}$ ) during the rest of the cycle at the day 18 . Table 5 and Figure 3 show serum levels of estradiol-17 $\beta$ and progesterone during the last 3 weeks of pregnancy and after parturition. Estradiol-17 $\beta$ level increased gradually before parturition and reached the highest $(\mathrm{P}<0.05)$ concentration $(628 \mathrm{pg} / \mathrm{ml})$ at the $6^{\text {th }}$ day before giving birth. On the day of parturition, estradiol-17 $\beta$ decreased $(\mathrm{P}<0.05)$ sharply to $42.97 \mathrm{pg} / \mathrm{ml}$. On the other hand, progesterone levels ranged from 4 to $6.5 \mathrm{ng} / \mathrm{ml}$ during the last two weeks before parturition, dropped to $2.5 \mathrm{ng} / \mathrm{ml}$ on the day of parturition, then ranged from 1.19 to $2.28 \mathrm{ng} / \mathrm{ml}$ after parturition.

Table 4. Concentrations of serum estradiol and progesterone hormones in estrous camels (mean \pm S.D).

\begin{tabular}{ccc}
\hline Days & Estradiol $(\mathbf{p g} / \mathbf{m l})$ & Progesterone $(\mathbf{n g} / \mathbf{m l})$ \\
\hline 0 (Estrus) & $29.69 \pm 7.31_{\mathrm{a}}$ & $0.56 \pm 0.59$ \\
1 & $13.89 \pm 8.74_{\mathrm{b}}$ & $0.50 \pm 0.21$ \\
3 & $6.90 \pm 1.59 \mathrm{~b}$ & $0.69 \pm 0.50$ \\
7 & $5.72 \pm 4.55_{\mathrm{b}}$ & $1.14 \pm 0.79$ \\
11 & $12.44 \pm 3.72_{\mathrm{b}}$ & $1.80 \pm 1.85$ \\
15 & $12.71 \pm 6.13_{\mathrm{b}}$ & $1.18 \pm 0.59$ \\
18 & $10.63 \pm 2.36_{\mathrm{b}}$ & $1.03 \pm 0.82$ \\
\hline${ }_{\mathrm{a}, \mathrm{b}}^{\mathrm{b}}$ Denote differences between means in the same column $(\mathrm{P}<0.05)$.
\end{tabular}


Table 5. Concentrations of serum estradiol and progesterone hormones in camels during the last month of pregnancy and after parturition (3 days intervals, mean \pm S.D).

\begin{tabular}{ccc}
\hline Days & Estradiol $(\mathbf{p g} / \mathbf{m l})$ & Progesterone $(\mathbf{n g} / \mathbf{m l})$ \\
\hline-18 & $240.95 \pm 161.34_{\mathrm{bc}}$ & $1.40 \pm 0.58_{\mathrm{c}}$ \\
-15 & $393.96 \pm 159.46_{\mathrm{ab}}$ & $4.96 \pm 3.08_{\mathrm{ab}}$ \\
-12 & $503.74 \pm 268.94_{\mathrm{ab}}$ & $4.08 \pm 3.78_{\mathrm{abc}}$ \\
-9 & $553.72 \pm 146.10_{\mathrm{a}}$ & $5.30 \pm 2.81_{\mathrm{ab}}$ \\
-6 & $628.29 \pm 222.37_{\mathrm{a}}$ & $4.25 \pm 3.03_{\mathrm{abc}}$ \\
-3 & $488.55 \pm 411.65_{\mathrm{ab}}$ & $6.45 \pm 0.64_{\mathrm{bc}}$ \\
Parturition & $42.97 \pm 60.39_{\mathrm{c}}$ & $2.47 \pm 0.46_{\mathrm{bc}}$ \\
3 & $16.04 \pm 7.45_{\mathrm{c}}$ & $1.88 \pm 1.19_{\mathrm{bc}}$ \\
6 & $38.75 \pm 41.65_{\mathrm{c}}$ & $2.28 \pm 1.69_{\mathrm{c}}$ \\
9 & $20.36 \pm 13.47 \mathrm{c}$ & $1.19 \pm 0.38_{\mathrm{c}}$ \\
\hline a, b, c ${ }^{\circ}$ Denote differences between means in the same column $(\mathrm{P}<0.05)$.
\end{tabular}

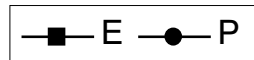

535

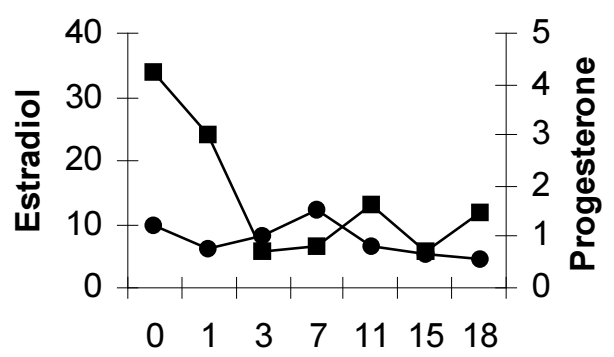

107

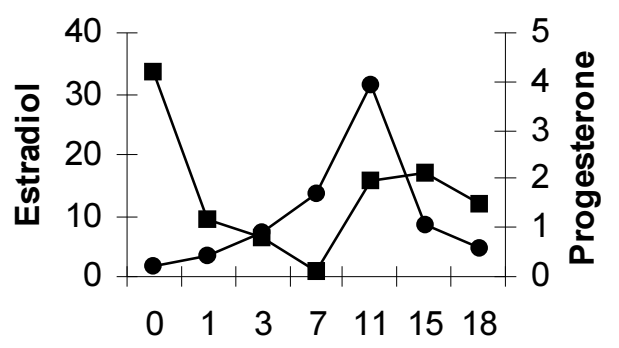

196

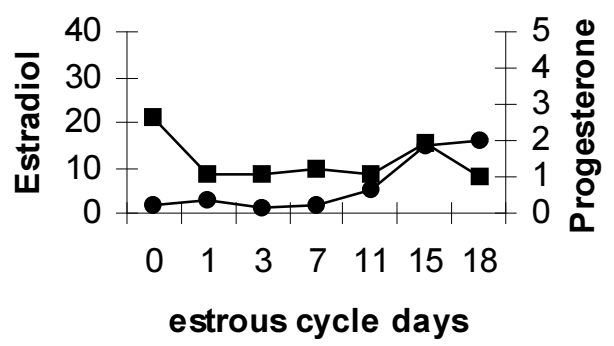

Figure 2. Serum levels of estradiol $(\mathrm{pg} / \mathrm{ml})$ and progesterone $(\mathrm{ng} / \mathrm{ml})$ in 3 camels during estrous cycle. 


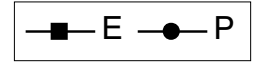

102

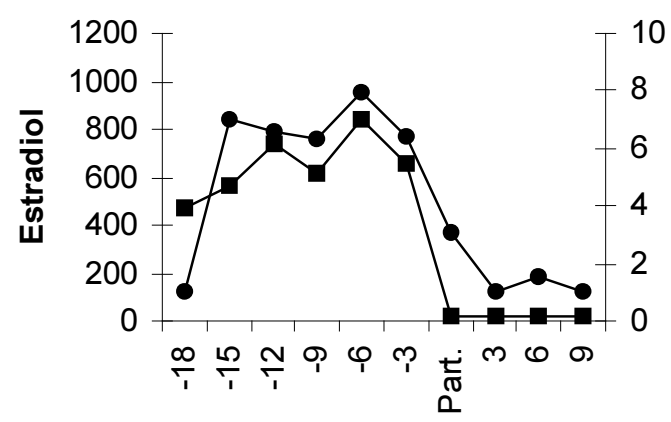

306

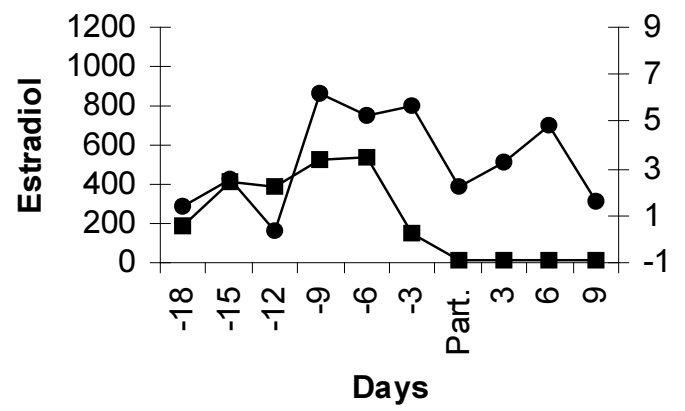

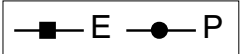

152

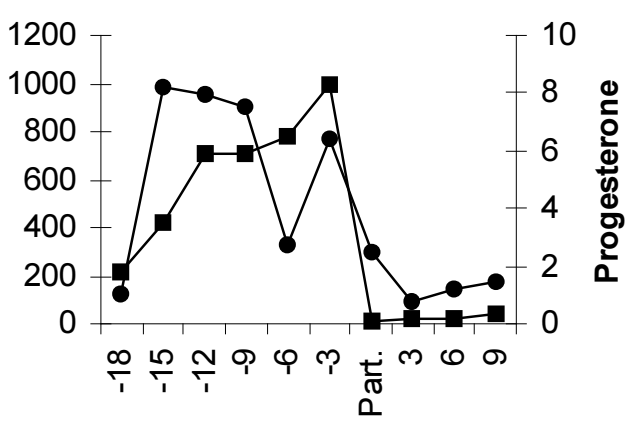

107

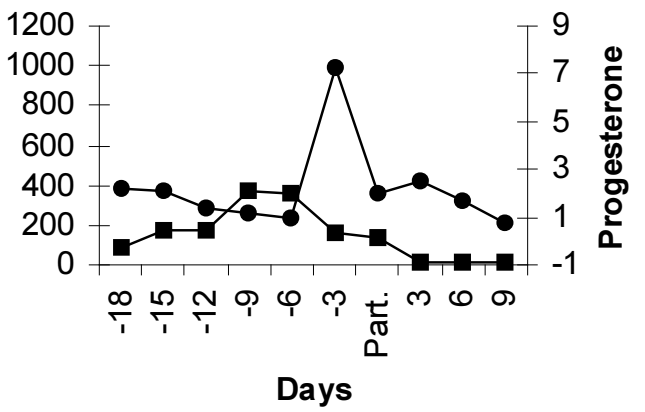

Figure 3. Serum levels of estradiol $(\mathrm{pg} / \mathrm{ml})$ and progesterone $(\mathrm{ng} / \mathrm{ml})$ in 4 camels near end of pregnancy and after parturition

\section{Discussion}

Blood is an important index for several metabolic processes in the body that may in one animal species vary due to age, sex, physiological condition, and environmental factors etc. The values for hematological and biochemical parameters determined in the present study (Table 1 and 2) were in the normal ranges and are in agreement with other studies by Abdel Gadir et al. (1984), Higgins and Kock (1985) and Nyang'ao et al. (1997). The total number of white blood cells (10.54 to $11.28 \times 10^{3}$ $/ \mathrm{ml})$ determined in the present study was higher than those reported (2.9 to $9.7 \times 10^{3}$ $/ \mathrm{ml})$ by Higgins and Kock (1985) and lower than those reported $\left(8.8\right.$ to $30 \times 10^{3}$ $/ \mathrm{ml}$ ) by Nyang'ao et (1997). This could be due to breed differences. Ghodsian et al. (1978) reported that white blood cell numbers in young camels are usually higher than those of adults which agrees with our findings. They attributed that to the higher number of band cells, neutrophils, monocytes, eosinophils and basophils in younger camels. The predominant white cells observed in the present study were neutrophils followed by lymphocytes and are in agreement with results reported by Ghodsian et al. (1978) and Higgins and Kock (1985). The higher values observed for neutrophils and eosinophils in pregnant than in nonpregnant camels could be due to age differences and to the stress of pregnancy. Most of the biochemical parameters obtained in the present study are in close agreement with previous results (Elias and Yagil, 1984; Al-Ali et al., 1988 and Beaunoyer, 1992). However, higher levels in most of the determined biochemical 
parameters were found in the non-pregnant than in pregnant camels. In the present study, values for total protein, albumin, blood urea nitrogen and creatinine were higher in pregnant than in non-pregnant camels. This could be due to differences in age and physiological conditions (pregnancy) between both groups of camels. Jain (1993) reported that plasma total protein concentrations were comparatively higher in old animals. In addition, Rezakhani et al. (1997) found that the concentration of urea nitrogen, total protein and globulin increased with age in Iranian camels. However, some authors reported opposite findings and attributed that to differences in breed and climatic conditions.

In the present study, the immature camels (3-4 years old) did not show estrus signs throughout the experiment as checked by the presence of a rutting male camel with females for two hrs every day. Iwema (1960) stated that a young she-camel may come in season at 3 years and first service is generally allowed at the age of 4 years, while Matharu (1966) reported that the female camel does not generally bread until she is 6 years old. In Saudi Arabia, Arthur et al. (1985) reported that shecamels reach puberty at the age of 2 years but are not mated until they are 3 years of age. The factors influencing the age at puberty in camels have not been studied, but investigations on other farm animals revealed that puberty is genetically determined and is conditioned by environmental factors (Joubert, 1963), which affect body weight, organ growth, and nutritional status (Hunter, 1980). Chatty (1972) suggested that the old age of puberty in camels could be due to slow rate of growth. Schwartz et al. (1983) reported that under traditional nomadic management in Kenya, camels reach their mature body weight between 7 and 8 years of age.
Levels of estradiol-17 $\beta$ measured in the immature camels in the present study probably did not reach optimum concentrations to elicit estrus signs. The maximum level of estradiol-17 $\beta$ was 13.4 $\mathrm{pg} / \mathrm{ml}$ in those immature non-cycling camels (Table 3). However, estradiol-17 $\beta$ concentration in camels at estrus was 29.69 $\mathrm{pg} / \mathrm{ml}$ (Table 4). Skidmore et al. (1996a) reported in camels that estradiol-17 $\beta$ reached a peak value of $39.0 \mathrm{pg} / \mathrm{ml}$ when the dominant follicle measured $1.7 \mathrm{~cm}$ diameter at estrus. Abdel-Rahim (1989) stated that the presence of progesterone is necessary for the manifestation of estrus and sexual receptivity in camels. It also seems that the proper ratio between the two steroids is necessary for showing estrus signs in camels. Abdel-Rahim and ElNazier (1992) found in male camels that flehmen occurred for shorter periods of time with estrus, compared to non-estrus female camels, which could be due to the presence of the right pheromone in terms of quality and quantity in estrus urine. They suggested the presence of more than one pheromonal substances in camel urine, each of which could act independently or in combination, as is known to occur in sheep (Radford and Watson, 1957). In non-mated female camels the mature follicle becomes atretic and a new follicular wave soon initiates a new period of estrus and sexual receptivity (Skidmore et al, 1996a). The source of progesterone hormone in the present study in the noncycling animals could be from ovarian or adrenal sources. Arthur and Al-Rahim (1982) examined the genital organs of female camels from the abattoir and found that the numbers of corpora albicans exceeded the numbers expected from normal pregnancies. Marie and Anouassi (1987) observed that ovulation could occur in females exposed to the sight, sound, and smell of a male after a prolonged absence. However, plasma progesterone measurements in such animals indicate a 
short life span of the resulting corpus luteum (CL), as is the case in females that ovulate after a sterile mating (Elias, 1990). These observations might suggest that spontaneous ovulation could take place in the she-camel. El-Wishy (1987) reported that the camel is an induced ovulator, and the estrous cycles are either ovulatory or non-ovulatory (follicular). Thus the present study suggests that the source of progesterone hormone in the non cycling camels could be due to silent ovulation.

In the present study estradiol-17 $\beta$ and progesterone levels showed increases towards the end of pregnancy (Table 5). The steady increase in estradiol-17 $\beta$ level was also found in the cow (Robertson, 1974), Ilama (Leon et al. 1990), onehumped camel (Skidmore et al. 1996b) and Bactrian camel (Zhao et al. 1998). The maternal estradiol-17 $\beta$ dropped following parturition, indicating that the estradiol$17 \beta$ measured in pregnant camels was fetoplacental in origin. The level of progesterone did not change significantly during the last 15 days before giving birth, then decreased $(\mathrm{P}<0.05)$ after parturition. In sheep, the placenta at term possesses an active steroid $17 \alpha$-hydroxylase system (Anderson et al. 1975) and is able to convert $17 \alpha$-hydroxyprogesterone to estrogens in vitro (Steele et al. 1976). A similar situation may exist in the camel during the final months of pregnancy as observed by Elias et al. (1984) who found very high concentrations of estradiol-17 $\beta$ ( 241 to $390 \mathrm{ng} / \mathrm{ml}$ ) in the allantoic fluid of camels at birth. In addition, the increased production of estrogens coincides with an increase in fetal growth and a substantial increase in the volume of fetal fluids observed between 9 and 12.5 months of gestation in the dromedary (El-Wishy et al. 1981). This also suggests that placental estrogens are important for fetal growth in camels.

\section{Acknowledgement}

This research was made possible through the United Arab Emirates University Research Council under the multidisciplinary project number 01-612/99 "Development of Sustainable Camel Production System".

\section{References}

Abdel Gadir, S. E., A. G. A. Wahbi and O. F. Idris. 1984. Some blood and plasma constituents of camels. In: proceedings of the camelid, an all purpose animal. Scandinavian Institute of African Studies, Sweden, pp. 438-443.

Abdel-Rahim, S. E. A 1989. The use of milk progesterone analysis to monitor reproductive activity in the camel (Camelus dromedaries). British Vet. J. 145: 23-27.

Abdel-Rahim, S. E. A. and A.T. El-Nazier. 1992. Studies on the sexual behaviour of the dromedary camel. In: proceedings of $1^{\text {st }}$ international camel conference $2^{\text {nd }}-6^{\text {th }}$, Feb. 1992. (Eds. Allen W. K., Higgins, A. J., Mayhew, L. G., Snow, D. H. and J. F. Wade, R. W. Publications. Newmarket Ltd: Country 115-118.

Al-Ali, A. K., H. A. Husayni, and D. M. Power. 1988. A comprehensive biochemical analysis of the blood of the camel (Camelus dromedaries). Comp. Biochem. \& Physiol. 89b (1): 35-37.

Anderson, A. B. M, A. P. F. Flint and A. C. Turnbull. 1975. Mechanism of action of glucocorticoids in induction of ovine parturition: effect on placental steroid metabolism. J. Endocrinol. 66: 61-70. 
Arthur, G.H and A. T. Al-Rahim. 1982. Aspects of reproduction in the female camel (Camelus dromedaries) in Saudi Arabia. Vet Med. Rev. 41: 650-659.

Arthur, G. H., A. T. Al-Rahim and A. S. Al-Hindi. 1985. The camel in health and disease. 7. Reproduction and genital disease of the camel. British Vet. J. 41: 650-659.

Bassett, J. M., T. J. Oxborrow, I. D. Smith and G. D. Thorburn. 1969. The concentration of progesterone in the peripheral plasma of the pregnant ewe. J. Endocrinol. 45: 449-457.

Beaunoyer, D. E. 1992. Changes in serum enzyme activities after maximal exercise. In: Proceedings of first international camel conference 2nd$6^{\text {th }}$, Feb. (Eds. Allen W. K., Higgins, A. J., Mayhew, L. G., Snow, D. H. and Wade, J. F.) R. W. Publications. Newmarket : 331-333.

Chatty, D. 1972. Structural forces of pastoral nomadism with special reference to camel pastoral nomadism. The Hague Inst. of Social Studies, 96 pp.

Duncan, D. B. 1955. Multiple range and multiple F tests. Biometrics. 11:1.

Elias, E. 1990. Early weaning in the onehumped camel. "Is it possible to improve reproductive performance in the camel?" Proc. UCDEC Workshop, Paris.

Elias, E., E. Bedrak and R. Yagil. 1984. Oestradiol concentration in the serum of the one-humped camel (Camelus dromedaries) during the various reproductive stages. Gen. Comp. Endocrinol. 56: 258-264.
Elias, E. and R. Yagil. 1984. Hematological and serum biochemical values in lactating camels and their newborns. Refuah Vet. 41:7-13.

El-Wishy, A. B. 1987. Reproduction in the female dromedary (Camelus dromedaries): a review. Anim. Reprod. Sci. 12: 213-222.

El-Wishy, A. B., N. A. Hemeida, M. A. Omar, A. M. Mobarak, and M. A. I. ElSayed. 1981. Functional changes in the pregnant camel with special reference to fetal growth. British Vet. J. 137: 527-537.

Ghodsian, I, I. Nowrouzian and H. F. Schels. 1978. A study on some haematological parameters of Iranian camels. Tropical Anim. Health Prod. 10:109-110.

Higgins, A. J. and R. A. Kock. 1985. A guide to the clinical examination, chemical restraint and medication of the camel. In: The camel in health and in disease (Ed. Higgins, A. Bailliere Tindall, England, pp 21-40.

Hunter, R. H. F. 1980. Differentiation, puberty, and estrous cycle. In: Physiology and Technology of Reproduction in Female Domestic Animals. Academic Press, New York, pp. 1-34.

Iwema, S. 1960. The ship of the desert. Veeteelt Zuivelber 3: 390-394.

Jain, N. C. 1993. Essentials of Veterinary Haematology. Lea \& Febiger, Philadelphia. pp. 65-66.

Joshi, C. K., K. K. Vyas, P. K. Pareek. 1978. Studies on the oestrous cycle 
in Bikaneri she-camel. Indian $\mathrm{J}$. Anim.. Sci. 48:141-145.

Joubert, D. M. 1963. Puberty in female animals. Anim. Breed. Abst. 31: 295-306.

Leon, J.B., B. B Smith, K. I. Timm and G. LeCren. 1990. Endocrine changes during pregnancy, parturition and early post-partum period in the Ilama (Lama glama). J. Reprod. Fertil. 88:503-511.

Marie, M. and A. Anouassi. 1987. Induction of luteal activity and progesterone secretion in the nonpregnant one-humped camel (Camelus dromedaries). J. Reprod. Fertil. 80:183-192.

Matharu, B.S. 1966. Camel care. Indian Farming 16:19-22.

Musa, B. and M.E. Abusineina. 1978. The oestrous cycle of the camel (Camelus dromedaries). Vet. Rec. 103:556557.

Nyang'ao, J. M. N., W. Olah-Mukani, J. M Maribei and J. K. Omuse. 1997. A study of some haematological and biochemical parameters of the normal dromedary camel in Kenya. J. Camel Practice and Res. 4: 31-33.

Peterson, A.J., J.T. Hunter, R. A. S. Welch and R. J. Fairclough. 1975. Oestrogens in bovine fetal and maternal plasma near term. J. Reprod. Fertil. 43:179-181.

Radford, H. M. and R. H. Watson. 1957. Influence of rams on ovarian activity and oestrus in Merino ewes. Australian. J. Agric. Res. 8: 460-470.
Rezakhani, A., S. N. Habibabadi and M. M. Ghojogh. 1997. Studies on normal haematological and biochemical parameters of Turkmen camel in Iran. J. Camel Practice and Res. 4: 41-44.

Robertson, H. A. 1974. Changes in the concentration of unconjugated oestrone, oestradiol-17 $\alpha$ and oestradiol-17 $\beta$ in the maternal plasma of the pregnant cow in relation to the initiation of parturition and lactation. J. Reprod. Fertil. 36:1-7.

Robertson, H. A. and G. J. King. 1974. Plasma concentrations of progesterone, oestrone, oestradiol$17 \alpha$ and oestradiol-17 $\beta$ in the maternal plasma of the pregnant cow in relation to the initiation of parturition and lactation. J. Reprod. Fert. 36:1-7.

Schwartz, H. J., R. Dolan and A. J. Wilson. 1983. Camel production in Kenya and its constraints. I. Productivity. Tropical Anim. Health Prod. 15:169-178.

Skidmore, J. A, M. Billah and W. R. Allen. 1996a. The ovarian follicular wave pattern and induction of ovulation in the mated and nonmated one-humped camel (Camelus dromedaries). J. Reprod Fertil. 106: 185-192.

Skidmore, J. A, M. Billah and W. R. Allen. 1996b. Patterns of hormone secretion throughout pregnancy in the one-humped camel (Camels dromedaries). Reprod. Fertil. Dev. 8:863-869.

Snedecor, G. W. and W. G. Cochran. 1980. Statistical Methods. Iowa State Univ. Press, Ames, IA, USA. 
Steele, P. A., A. P. F. Flint and A. C. Turnbull. 1976. Activity of steroid C17,20 lyase in the ovine placenta: effect of exposure to fetal glucocorticoid. J. Endocrinol. 69:239-246.

Thorburn, G. D., D. H. Nicol, J. M. Bassett, D. A. Shutt and R. I. Cox. 1972. Parturition in the goat and sheep: changes in corticosteroids, progesterone, oesterogens and prostaglandin F2 $\alpha$. J. Reprod. Fertil. 16: 61-84.

Wilson, R. T. 1984. The Camel. Longmans, London.

Zhao, X. X, Y. Zhang, B. X. Chen. 1998. Serum progesterone and 17- $\beta$ estradiol concentrations during pregnancy of Bactrian camel (Camelus bactrianus). Theriogenology. 50:595-604. 